\title{
Soil Characteristics of Newly Reclaimed Tidal Land and Its Changes by Cultivation of Green Manure Crops
}

\author{
Kyeong-Bo Lee ${ }^{1 *}$, Jong-Gook Kang ${ }^{1}$, Kyeong-Do Lee ${ }^{2}$, Sanghun Lee ${ }^{1}$, Seon-Ah Hwang ${ }^{1}$, \\ Seon-Woong Hwang', and Hong-Kyu Kim ${ }^{1}$ \\ ${ }^{I}$ National Institute of Crop Science, RDA, Iksan 570-080, Korea \\ ${ }^{2}$ National Academy of Agricultural Science, RDA, Suwon 441-707, Korea
}

\begin{abstract}
This study was conducted to investigate the soil characteristics of newly reclaimed tidal land and the effect of green manure crops on soil properties. Summer green manure crops such as sesbania (Sesbania grandiflora), banyard grass (Echinochloa spp.) and sorghum $\times$ sudangrass hybrid (Sorghum bicolor L.) were cultivated at Hwaong, Ewon, Saemangeum and Yongsangang area. Soil pH of reclaimed tidal land was relatively high, but organic matter and available phosphorus contents were lower compared to the optimum range for common upland crops. Soil nutrient contents were unbalanced for upland crop growth. Yield of green manure crops had a wide spatial variation. Nitrogen content in green manure crops was the greater in Sesbania and it was estimated that major nutrient $\left(\mathrm{N}-\mathrm{P}_{2} \mathrm{O}_{5}-\mathrm{K}_{2} \mathrm{O}\right)$ supply amount were $150-40-370,220-50-170$ and $140-50-250 \mathrm{~kg}$ $\mathrm{ha}^{-1}$ from sorghum $\times$ sudangrass hybrid, sesbania and barnyard grass, respectively. Based on these results, desalination is required to grow the upland crops at newly reclaimed tidal lands and management practices are necessary to reduce the salt damage by resalinization during the growing seasons. To improve the productivity and increase the nutrient utilization rate, soil physicochemical properties need to be improved to the level for upland crops by application of organic matter and fertilizer.
\end{abstract}

Key words: Reclaimed tidal land, Green manure crop, Soil properties

\section{서 언}

우리나라의 국토는 평야지 보다 산지가 많아 활용할 수 있는 가용 토지가 적고, 쌀을 비롯한 식량을 생산할 수 있는 우량농경지는 산업화, 도시화에 따른 타 용도 전용 등으로 매년 급속히 감소되고 있는 추세이다 (Kim et al., 2013). 미래 경제사회의 변동 등을 감안한다면 식량의 안정적 공급 을 위한 최소한의 우량농지 및 농경지의 확보와 이에 대한 효과적 활용대책의 수립이 가장 큰 과제 중 하나라고 볼 수 있다 (Koo et al., 1998; Son et al., 2000). 이에 대한 대책 으로 우리나라 서남해안의 간척자원을 대상으로 농업 생산 의 안정적 유지를 위해 간척사업이 진행되어 왔다. 그간 간 척사업은 한정된 국토에서 도시화와 산업화로 인해 잠식되 는 농경지 및 산업단지를 대체 확보함으로써 식량의 안정적 공급 등 긍정적인 효과를 가져왔다 (Lee et al., 2003; Lee et al., 2007).

지금까지 간척사업은 국토가 좁은 한국, 네덜란드, 일본, 영국, 독일 등의 국가에서 국토확장 목적으로 진행되었으나 국토가 거대한 중국에서도 간척사업을 진행하고 있다 (Lee et al., 2006). 금후 간척지에서는 변화하는 농업환경에 발
맞추어 우리 국민의 주식인 벼는 물론 밭작물, 사료작물, 원 예작물 등 종합적인 작물재배 기반조성이 이루어 질 것이라 기대된다 (Lee et al., 2007). 우리나라의 간척지 토양은 벼 를 중심으로 한 논토양으로 조성되어 왔는데 이는 염농도가 낮은 관개수를 이용한 담수를 통해 염을 효과적으로 제거할 수 있으므로 밭토양으로 이용하는 것보다 토양 관리가 상대 적으로 쉽기 때문이다. 그러나 최근에는 간척지 논토양 중 심에서 탈피하여 경제성 있는 밭작물을 재배할 수 있는 토 양 관리 방법에 대한 연구가 진행되고 있다 (Lee et al., 2000; Park et al., 2008). 또한, 간척지에서 친환경적으로 농경지가 조성되고 다양한 작물이 생산된다면 식량 중심의 소득은 물론 관광농업, 농업체험 학습장 등 새로운 형태의 소득도 창출될 것으로 생각된다. 이러한 다양한 식물을 활 용한 생물 산업을 활성화시키기 위해서는 국내외 선진사례 를 중심으로 우리 실정에 맞는 기술 개발과 연구가 시급한 실정이다. 따라서, 본 실험에서는 간척지의 다각적 활용 측 면에서 간척지 밭작물 도입 방안을 검토하기 위하여 화옹, 이원, 새만금, 영산강 지구의 신간척지를 대상으로 밭작물 을 재배하여 간척지구별 토양환경을 평가하고 작물별 생육 상황을 조사 분석하고자 한다.

\footnotetext{
접수 : 2013. 2. 14 수리 : 2013. 4. 1

*연락저자 : Phone: +82638402108

E-mail: lee1214@korea.kr
} 
Table 1. Chemical properties of the experimental sites before crop cultivation.

\begin{tabular}{|c|c|c|c|c|c|c|c|c|c|c|}
\hline \multirow{2}{*}{ Area } & \multirow{2}{*}{ Depth } & \multirow{2}{*}{$\mathrm{pH}$} & \multirow{2}{*}{$\mathrm{EC}$} & \multirow{2}{*}{ Av. $\mathrm{P}_{2} \mathrm{O}_{5}$} & \multirow{2}{*}{$\mathrm{T}-\mathrm{N}$} & \multirow{2}{*}{$\mathrm{OM}$} & \multicolumn{4}{|c|}{ Exch. Cations } \\
\hline & & & & & & & $\mathrm{Ca}$ & $\mathrm{K}$ & $\mathrm{Mg}$ & $\mathrm{Na}$ \\
\hline \multirow{3}{*}{ Hwaong } & $\mathrm{cm}$ & $1: 5$ & $\mathrm{dS} \mathrm{m}^{-1}$ & $m g \mathrm{~kg}^{-1}$ & \multicolumn{2}{|c|}{-- $\mathrm{g} \mathrm{kg}^{-1}--$} & \multicolumn{4}{|c|}{--- $\mathrm{cmol}_{\mathrm{c}} \mathrm{kg}^{-1}$} \\
\hline & $0-15$ & 7.5 & 4.3 & 28 & 0.50 & 9.6 & 3.4 & 1.64 & 4.8 & 6.9 \\
\hline & $15-30$ & 7.8 & 5.8 & 32 & 0.40 & 9.3 & 3.3 & 1.89 & 4.6 & 8.6 \\
\hline \multirow{2}{*}{ Ewon } & $0-15$ & 8.8 & 14.3 & 14 & 0.18 & 4.5 & 4.7 & 1.47 & 5.2 & 9.0 \\
\hline & $15-30$ & 9.0 & 11.1 & 8 & 0.10 & 2.7 & 5.8 & 1.25 & 4.0 & 6.8 \\
\hline \multirow{2}{*}{ Saemangum } & $0-15$ & 7.6 & 5.3 & 26 & 0.16 & 0.8 & 1.1 & 1.18 & 3.6 & 8.0 \\
\hline & $15-30$ & 7.7 & 10.4 & 26 & 0.16 & 1.1 & 1.2 & 1.10 & 3.2 & 7.1 \\
\hline \multirow{2}{*}{ Yongsangang } & $0-15$ & 7.7 & 5.2 & 14 & 0.43 & 10.0 & 8.0 & 0.86 & 3.8 & 2.2 \\
\hline & $15-30$ & 8.1 & 1.8 & 12 & 0.32 & 8.1 & 7.6 & 0.70 & 2.6 & 1.6 \\
\hline Optimum ranges & & $65-70$ & - & $150-250$ & - & $20-30$ & $6.0-7.0$ & $0.45-0.55$ & $2.0-2.5$ & - \\
\hline
\end{tabular}

\section{Materials and Methods}

시험포장 본 연구는 서남해안의 간척지인 화옹, 이원, 새만금, 영산강 지구를 대상으로 수행하였다. 화옹 지구는 경기도 화성시에, 이원 지구는 충청남도 태안군에, 새만금 지구는 전라북도 군산시, 김제시 그리고 부안군에 걸쳐 있 고, 영산강 지구는 전라남도 목포시, 나주시, 무안군, 영암 군 그리고 함평군에 걸쳐 위치해 있다. 선행연구를 통하여 검토한 결과 (Lee et al., 2007) 활용 가치가 비교적 크다고 밝혀진 여름철 녹비작물인 세스바니아 (Sesbania grandiflora), 제주재래피 (Echinochloa spp.), 수수수단그라스 (Sorghum bicolor L.) 3작물을 재배하면서 이들 작물의 생육과 토양의 이화학성의 변화를 조사하고자 하였다.

작물재배 녹비작물 재배방법은 세스바니아, 제주재래 피 및 수수수단그라스를 선발하여 종자를 6월 상순에 조 간 $40 \mathrm{~cm}$ 로 $40 \mathrm{~kg} \mathrm{ha}^{-1}$ 씩 조파하였고 시비는 유안과 용과 린, 황산칼리를 성분량 $\left(\mathrm{N}-\mathrm{P}_{2} \mathrm{O}_{5}-\mathrm{K}_{2} \mathrm{O}\right)$ 으로 각각 세스바니아 는 60-80-60, 제주재래피는 150-100-100, 수수×수단그라 스는 200-150-150 kg ha-1 수준으로 하였다. 질소는 50-50 으로 분시하였으며, 인산과 칼리 비료는 전량 기비로 공급 하였다.

작물 생육 및 수량 작물의 초장은 측정은 작물 지상부 전체 길이를 측정하였으며, 수확은 개화기에 실시하였다. 생초수량은 단위면적 당 $\left(1 \mathrm{~m}^{2}\right)$ 전체 식물체를 수확한 후 즉 시 칭량하여 구하였고, 건조수량은 생초 $1 \mathrm{~kg}$ 상당량을 6 $0^{\circ} \mathrm{C}$ 에서 60 시간 건조하여 무게를 칭량하여 건물률을 구한 후 생초수량에 건물률을 곱하여 구하였다.

토양 및 식물체 분석 토양의 화학성은 토양시료를 표
토 (0-15 cm)와 심토 $(15-30 \mathrm{~cm})$ 로 구분하여 채취하여 음 건 후 세토를 분석시료로 사용하였다. 토양분석방법은 농촌 진흥청 토양화학성분석법 (NIAST, 2000)에 준하여 $\mathrm{pH}$ 및 $\mathrm{EC}$ 는 초자전극법, 유효인산 $\left(\mathrm{Av} . \mathrm{P}_{2} \mathrm{O}_{5}\right)$ 은 Lancaster법, 총 질소 (T-N)는 Indophenol blue법, 토양유기물 (OM)은 Tyurin 법, 치환성양이온 (Exch. $\mathrm{Ca}, \mathrm{K}, \mathrm{Mg}, \mathrm{Na}$ )은 $1 \mathrm{~N}-\mathrm{NH}_{4} \mathrm{OAC}$ $(\mathrm{pH}$ 7.0)으로 추출하여 유도결합플라즈마 발광광도계 (ICP, Varian)로 분석하였다. 토양의 물리성은 토양시료를 표토 $(0-15 \mathrm{~cm})$ 와 심토 $(15-30 \mathrm{~cm})$ 로 구분하여 $100 \mathrm{~cm}^{3}$ 코아로 채취하여 고상, 액상, 기상의 3상 비율과 용적밀도 및 공극 률을 구하였다. 토양 중 투수속도는 오거홀에 물을 붓고 일 정 시간간격별로 줄어드는 물의 양과 시간을 기록하는 역오 거혈법 (Park and Yoo, 1983)을 이용하였다.

식물체 분석시료는 각 작물을 채취한 후 증류수로 3 회 이 물질을 제거한 다음 $60^{\circ} \mathrm{C}$ 로 60 시간 온풍건조기에서 건조한 후 60 mesh로 분쇄하여 조제하였다. 식물체 양분함량은 조 제한 시료를 $\mathrm{H}_{2} \mathrm{O}_{2}-\mathrm{H}_{2} \mathrm{SO}_{4}$ 습식분해한 후 인산 $\left(\mathrm{P}_{2} \mathrm{O}_{5}\right)$ 은 Vanadate법, 질소 $(\mathrm{T}-\mathrm{N})$ 는 Indophenol blue법, $\mathrm{CaO}, \mathrm{K}_{2} \mathrm{O}$, $\mathrm{MgO}, \mathrm{Na}_{2} \mathrm{O}$ 는 $\mathrm{ICP}$ 로 측정하였다.

\section{Results and Discussion}

간척지구별 시험 전 토양의 화학적 특성 간척지구 별 시험 전 토양의 이화학적 특성은 Table 1 과 같았다. 화옹 지구는 표토의 경우 $\mathrm{pH}$ 는 7.5 로 밭토양의 적정범위 (6.5-7.0) 보다 다소 높았고, 유효인산 및 유기물의 함량은 각각 28 $\mathrm{mg} \mathrm{kg}$ 과 $9.6 \mathrm{~g} \mathrm{~kg}^{-1}$ 으로 밭토양의 적정범위보다 현저히 낮았다. 치환성 칼륨과 마그네슘의 함량은 적정범위보다 2 배 이상 높게 나타났으나, 치환성 칼슘의 함량은 적정범위 보다 낮았다. 심토의 화학성분 변화는 $\mathrm{pH}$ 는 7.8 범위로 깊 이별로 차이가 없었으며, $\mathrm{EC}$ 는 표토가 4.3 , 심토가 $5.8 \mathrm{dS}$ 
Table 2. Physical properties of the experimental sites before crop cultivation.

\begin{tabular}{|c|c|c|c|c|c|c|c|c|c|c|}
\hline \multirow{2}{*}{ Area } & \multirow{2}{*}{ Depth } & \multirow{2}{*}{$\begin{array}{c}\text { Bulk } \\
\text { density }\end{array}$} & \multicolumn{3}{|c|}{ Three phases } & \multirow{2}{*}{ Porosity } & \multicolumn{3}{|c|}{ Particle size distribution } & \multirow{2}{*}{ Texture } \\
\hline & & & Solid & Liquid & Gaseous & & Sand & Silt & Clay & \\
\hline & $\mathrm{cm}$ & $\mathrm{Mg} \mathrm{\textrm {m } ^ { - 3 }}$ & - & - \% - & 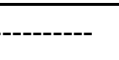 & $\%$ & - $-\cdots$ & $-\%-$ & ---- & \\
\hline \multirow{2}{*}{ Hwaong } & $0-15$ & 1.35 & 51.1 & 37.3 & 11.6 & 48.9 & 7.6 & 83.7 & 8.7 & Silt \\
\hline & $15-30$ & 1.41 & 53.3 & 41.8 & 4.9 & 46.7 & 36.5 & 53.5 & 10.0 & Silt loam \\
\hline \multirow{2}{*}{ Ewon } & $0-15$ & 1.48 & 55.9 & 27.4 & 16.7 & 44.1 & 82.8 & 13.2 & 4.0 & Loamy sand \\
\hline & $15-30$ & 1.60 & 60.5 & 34.5 & 4.9 & 39.5 & 84.5 & 10.5 & 5.0 & Loamy sand \\
\hline \multirow{2}{*}{ Saemangum } & $0-15$ & 1.44 & 54.2 & 30.6 & 15.2 & 45.8 & 69.0 & 28.9 & 2.1 & Sandy loam \\
\hline & $15-30$ & 1.48 & 56.0 & 29.9 & 14.1 & 44.0 & 70.3 & 25.7 & 4.0 & Sandy loam \\
\hline \multirow{2}{*}{ Yongsangang } & $0-15$ & 1.55 & 58.5 & 22.2 & 19.3 & 41.5 & 53.4 & 35.6 & 11.0 & Loam \\
\hline & $15-30$ & 1.55 & 58.4 & 22.0 & 19.6 & 41.6 & 71.4 & 20.6 & 8.0 & Sandy loam \\
\hline
\end{tabular}

Table 3. Saturated hydraulic conductivity of each experimental site.

\begin{tabular}{lcccc}
\hline \hline & Hwaong & Ewon & Saemangum & Yongsangang \\
\hline \multirow{2}{*}{ Hydraulic Conductivity } & $--1-0-1-0-1$ & 25.17 & 16.8 \\
\hline
\end{tabular}

$\mathrm{m}^{-1}$ 로 토심이 깊을수록 높은 경향을 나타냈다. 치환성 나트 륨함량은 표토가 6.9 , 심토가 $8.6 \mathrm{cmolc} \mathrm{kg}^{-1}$ 으로 다른 시험 포장보다 함량이 높았다. 이원 지구의 $\mathrm{pH}$ 는 8.8-9.0으로 아주 높게 나타났으며 $\mathrm{EC}$ 는 표토가 14.3 , 심토가 $11.1 \mathrm{dS}$ $\mathrm{m}^{-1}$ 로 조사지역 토양 중 $\mathrm{pH}$ 와 염분함량이 가장 높았다. 총 질소는 $0.10-0.18 \mathrm{~g} \mathrm{~kg}-1$ 이었으며, 유기물함량은 2.7-4.5 $\mathrm{g} \mathrm{kg}^{-1}$ 이었다. 치환성 양이온 함량은 칼슘을 제외하고 토심 이 깊을수록 낮았으며 나트륨은 표토가 $9.0 \mathrm{cmolc} \mathrm{kg}^{-1}$, 심 토가 $6.8 \mathrm{cmolc} \mathrm{kg}^{-1}$ 이었다. 새만금 지구의 토양 $\mathrm{pH}$ 는 7.6-7.7 범위로 토심에 따라 차이가 없었으며, $\mathrm{EC}$ 는 표토가 5.3 , 심토가 $10.4 \mathrm{dS} \mathrm{m}^{-1}$ 로 심토가 높았다. 유효인산과 토양 유기물은 밭토양 적정범위보다 현저히 낮았으며 특히 유기 물의 함량은 조사지역 토양 중 가장 낮았다. 치환성 양이온 의 경우 칼슘은 적정범위보다 낮았고, 칼륨과 마그네슘은 적정범위보다 높았으며 나트륨함량은 표토가 8.0, 심토가 $7.1 \mathrm{cmolc} \mathrm{kg}^{-1}$ 이었다. 영산강 지구는 표토의 경우 토양 $\mathrm{pH}$ 는 7.7로 다소 높았으며 토심이 깊어질수록 높게 나타났다. $\mathrm{EC}$ 는 표토가 5.2 , 심토가 $1.8 \mathrm{dS} \mathrm{m}^{-1}$ 로 표토의 염분함량이 심토보다 높았다. 유효인산, 총질소, 토양유기물의 함량은 표토가 심토보다 높았으나 밭토양 적정범위보다 낮게 나타 났다. 치환성 양이온의 경우 분석한 4 가지 성분 모두 표토 에서 심토보다 다소 높았다. 조사지역 중 칼슘의 함량이 가 장 높아 유일하게 밭토양 적정범위보다 높았으며, 치환성 나트륨 함량은 조사지역 중 가장 낮았다.

간척지구별 시험 전 토양의 물리적 특성 간척지구 별 토성을 보면 (Table 2) 화옹 지구의 표토는 미사의 함량
이 많은 미사질토이였으며, 심토는 미사질 양토로 표토보다 모래의 함량이 높았다. 이원 지구는 표토와 심토 모두 양질 사토로 4 지역 중 모래의 함량이 가장 많았다. 새만금 지구 의 토성은 사양토이었으며, 영산강 지구의 토성은 표토가 양토로 4지역 중 점토의 함량이 가장 높았으며 심토는 사양 토로 나타났다. 간척지구별 용적밀도는 $1.35-1.60 \mathrm{Mg} \mathrm{m}^{-3}$ 범위로 일반적인 토양의 용적밀도인 $1.20-1.35 \mathrm{Mg} \mathrm{m}^{-3}$ 보다 높은 값을 나타냈다. 이는 지력이 약하고 토양의 구조가 발 달되지 않아 투수성과 통기성이 나쁘기 때문에 토양층이 굳 어져 용적밀도가 높아지는 간척지 토양의 특성 때문일 것으 로 생각된다. 간척지구별로는 커다란 차이를 보이지 않았으 나 다른 조사지역에 비해 모래함량이 적고 유기물함량이 높 은 화옹 지구의 경우 용적밀도가 가장 낮았다. 조사지역 토 양의 공극률은 39.5-48.9\% 범위로 간척지구별 커다란 차이 를 보이지 않았으며, 토심에 따른 차이도 크지 않았다.

토양 중 투수속도를 측정한 결과 (Table 3), 모래 함량이 많은 사양토 계열의 영산강, 이원 및 새만금 지구의 경우 투 수 속도가 각각 $16.8,19.21$ 및 $25.17 \mathrm{~cm} \mathrm{day}^{-1}$ 로 양호하여 수직배수에 유리할 것으로 판단된다. 그러나 토양 중 투수 속도가 빠르다고 해서 물이 대기와 접해있는 토양표면을 통 과하는 침투속도까지 빠른 것은 아니며, $\mathrm{Na}$ 함량이 높은 이 원 지구의 경우 토양 표면이 $\mathrm{Na}$ 에 의해 경화되어 물리성이 불량해지고 수분의 이동도 어렵기 때문에 토양 표면의 $\mathrm{Na}$ 함량을 줄일 수 있는 개량제의 살포 및 경운 등의 물리성 개 선 작업으로 지표면의 물이 지중으로 이동할 수 있도록 하 는 작업도 필요하리라 생각된다. 미사 및 점토 함량이 다른 지구에 비해 많은 화옹 지구에서는 투수속도가 $2 \mathrm{~cm}^{-1} \mathrm{day}^{-1}$ 
이하로 불량하여 밭작물 재배를 위한 수직배수 개선이 필요 할 것으로 생각되며, 수직 배수가 불량한 이들 지역에서 밭 작물 재배를 위해서는 습해에 잘 견딜 수 있는 작물의 선정 및 수직배수 개선을 위한 암거 등의 시설이 필요할 것으로 판단된다.

간척지구별 작물 생육 및 식물체 성분 변화 간척지 구별 작물의 초장을 측정한 결과 수수 $\times$ 수단그라스, 세스바 니아, 제주재래피 모두 새만금 지구에서 가장 큰 값을 보였 고, 화옹 지구에서 가장 작았다 (Fig. 1). 작물별 초장은 수 수×수단그라스의 경우 8월, 9월 모두 새만금>영산강>이원> 화옹 순이였고, 세스바니아는 지역별로 8월의 초장과 9 월의 초장이 다른 양상을 보였는데, 8월에는 새만금>화옹>이원> 영산강 순이였으나 9 월에는 새만금>영산강>화옹>이원 순이 었다. 제주재래피의 초장도 수수 $\times$ 수단그라스와 마찬가지로 9 월에 새만금>영산강>이원>화옹 순으로 나타났다. 간척지 구별 작물의 청예수량을 조사한 결과, 수수 $\times$ 수단그라스, 세스바니아, 제주재래피 모두 새만금 지구에서 가장 높았다 (Fig. 2). 작물별 청예수량은 세스바니아의 경우 새만금화 옹>이원>영산강 순이었고, 수수 $\times$ 수단그라스의 경우 새만 금>영산강>이원>화옹 순이었다. 제주재래피는 세스바니아 와 마찬가지로 새만금>화옹>이원>영산강 순이었다. 작물별 청예수량을 보면 화옹, 이원 지구의 경우 세스바니아가 수 수×수단그라스나 제주재래피보다 수량이 많았고, 새만금과 영산강에서는 수수 $\times$ 수단그라스의 청예수량이 가장 많았다. 간척지구별 작물의 건물수량을 조사한 결과, 수수 $\times$ 수단그 라스, 세스바니아 그리고 재래피는 새만금 지구에서 가장 높았다. 작물별 건물수량은 세스바니아의 경우 새만금>화

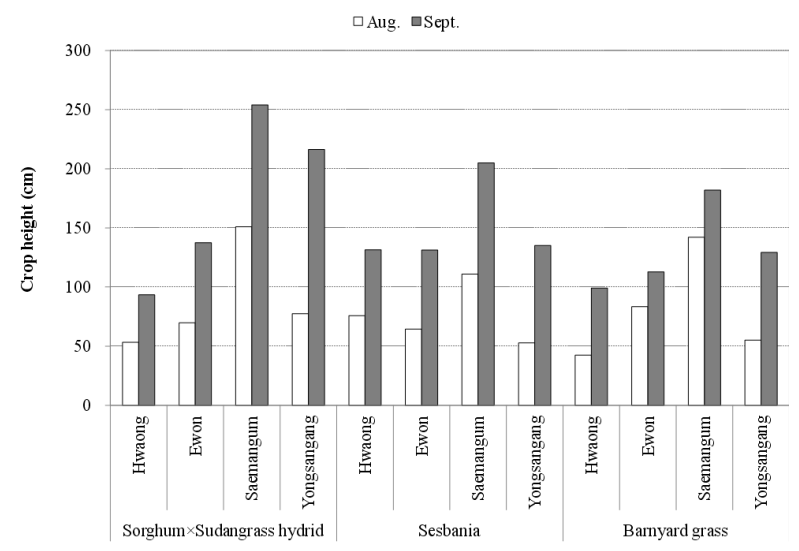

Fig. 1. The seasonal changes of green manure crop height in the experimental sites.

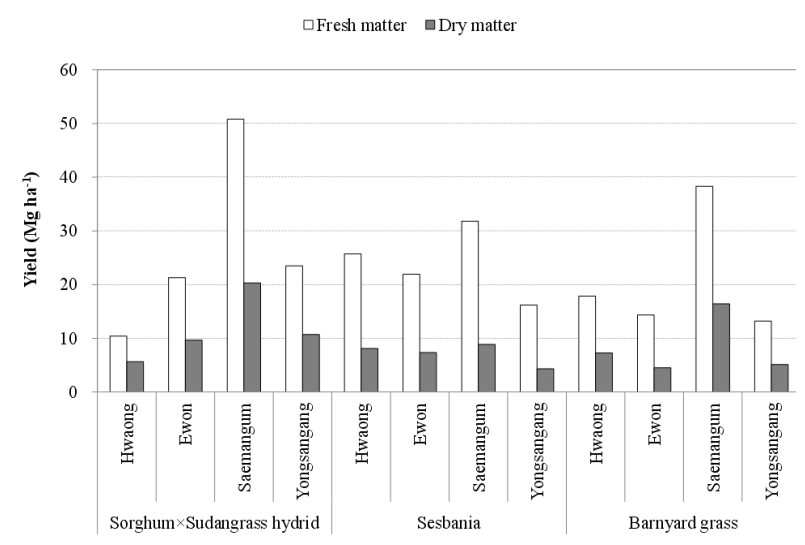

Fig. 2. Biomass of green manure crops grown in the experimental sites.

Table 4. Chemical properties of green manure crops at termination time in the experimental sites.

\begin{tabular}{|c|c|c|c|c|c|c|c|c|c|c|c|c|c|}
\hline \multirow{2}{*}{ Area } & \multirow{2}{*}{ rop } & \multicolumn{2}{|c|}{$\mathrm{P}_{2} \mathrm{O}_{5}$} & \multicolumn{2}{|c|}{ T-N } & \multicolumn{2}{|c|}{$\mathrm{CaO}$} & \multicolumn{2}{|c|}{$\mathrm{K}_{2} \mathrm{O}$} & \multicolumn{2}{|c|}{$\mathrm{MgO}$} & \multicolumn{2}{|c|}{$\mathrm{Na}_{2} \mathrm{O}$} \\
\hline & & Aug. & Sept. & Aug. & Sept. & Aug. & Sept. & Aug. & Sept. & Aug. & Sept. & Aug. & Sept. \\
\hline & & \multicolumn{12}{|c|}{ 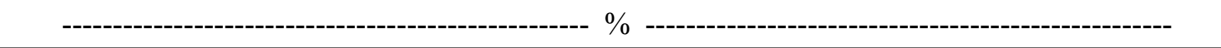 } \\
\hline \multirow{3}{*}{ Hwaong } & SS hybrid ${ }^{\dagger}$ & 0.40 & 0.50 & 0.90 & 0.65 & 0.16 & 0.13 & 2.71 & 1.66 & 0.41 & 0.35 & 0.21 & 0.19 \\
\hline & Sesbania & 0.55 & 0.40 & 2.75 & 1.69 & 0.84 & 0.40 & 4.10 & 1.39 & 0.36 & 0.18 & 0.65 & 0.42 \\
\hline & Barnyard grass & 0.54 & 0.49 & 1.30 & 0.77 & 0.21 & 0.13 & 2.59 & 1.41 & 0.61 & 0.35 & 1.44 & 0.79 \\
\hline \multirow{3}{*}{ Ewon } & SS hybrid & 0.45 & 0.34 & 1.43 & 0.94 & 0.39 & 0.31 & 2.48 & 1.64 & 0.41 & 0.29 & 0.67 & 0.14 \\
\hline & Sesbania & 0.60 & 0.39 & 2.09 & 1.88 & 0.81 & 0.66 & 3.32 & 1.56 & 0.32 & 0.20 & 0.98 & 0.37 \\
\hline & Barnyard grass & 0.47 & 0.51 & 1.67 & 1.63 & 0.37 & 0.35 & 3.13 & 1.66 & 0.51 & 0.39 & 1.70 & 0.91 \\
\hline \multirow{3}{*}{ Saemangum } & SS hybrid & 0.54 & 0.21 & 1.29 & 0.72 & 1.29 & 0.09 & 0.59 & 1.81 & 2.02 & 0.25 & 1.38 & 0.04 \\
\hline & Sesbania & 0.77 & 0.57 & 2.69 & 2.51 & 1.13 & 0.64 & 0.58 & 1.94 & 2.00 & 0.27 & 1.18 & 0.21 \\
\hline & Barnyard grass & 0.74 & 0.32 & 1.01 & 0.84 & 1.05 & 0.13 & 0.60 & 1.51 & 1.91 & 0.30 & 0.79 & 0.33 \\
\hline \multirow{3}{*}{ Yongsangang } & SS hybrid & 0.63 & 0.47 & 1.60 & 0.74 & 0.36 & 0.30 & 3.10 & 3.02 & 0.49 & 0.34 & 0.08 & 0.07 \\
\hline & Sesbania & 0.61 & 0.63 & 2.36 & 2.25 & 0.86 & 0.95 & 3.66 & 1.77 & 0.28 & 0.21 & 0.40 & 0.19 \\
\hline & Barnyard grass & 0.60 & 0.48 & 2.01 & 0.70 & 0.39 & 0.23 & 3.39 & 1.37 & 0.67 & 0.30 & 0.71 & 0.44 \\
\hline
\end{tabular}

${ }^{\dagger}$ SS hybrid, sorghum $\times$ sudangrass hybrid 
옹>이원>영산강 순으로 청예수량과 경향이 같았고, 수수 $\times$ 수단그라스의 경우에도 새만금>영산강>이원>화옹 순으로 청예수량과 경향이 같았으나 제주재래피의 건물수량은 새만 금>화옹>영산강>이원 순이었다. 이와 같이 새만금 지역의 좋은 작물 생육 발달은 수리전도도와 같은 토양의 물리적 특 성이 다른 지역에 비해 유리했기 때문인 것으로 판단된다.

간척지구별 작물의 생육시기별 식물체 성분 변화는 Table 4에 나타냈다. 화옹 지구에서 생육시기별 식물체 화 학성분의 변화를 보면 재배된 식물체중 $\mathrm{P}_{2} \mathrm{O}_{5}$ 함량은 $0.40-0.55 \%$ 범위를 나타냈으며, 작물별 큰 차이가 없었다. $\mathrm{T}-\mathrm{N}$ 와 $\mathrm{K}_{2} \mathrm{O}$ 함량은 세스바니아가 다른 식물에 비해 월등히 높았으며 시기별 화학성분의 변화는 모든 성분이 8월에 더 높은 경향을 보였다. 이원 지구의 경우 식물체 중 $\mathrm{P}_{2} \mathrm{O}_{5}$, $\mathrm{T}-\mathrm{N}, \mathrm{CaO}, \mathrm{K}_{2} \mathrm{O}$ 의 함량은 세스바니아가 다른 식물에 비하 여 높았으며, $\mathrm{MgO}$ 와 $\mathrm{Na}_{2} \mathrm{O}$ 의 함량은 재래피가 약간 높았다. 시기별로는 큰 차이가 없었으나 9 월에 모든 화학성분의 함 량이 다소 낮아졌다. 새만금 지구의 경우 식물체 중 $\mathrm{P}_{2} \mathrm{O}_{5}$, $\mathrm{T}-\mathrm{N}, \mathrm{CaO}$ 함량은 세스바니아가 다른 식물에 비하여 높았
으며, $\mathrm{K}_{2} \mathrm{O}$ 와 $\mathrm{Na}_{2} \mathrm{O}$ 는 식물종류 간 차이가 없었다. $\mathrm{K}_{2} \mathrm{O}$ 는 모 든 식물이 8월 대비 9월에 증가하는 경향을 모였고, 그밖에 다른 화학성분들은 9 월이 되면서 감소하였다. 영산강 지구 의 경우 식물체 중 $\mathrm{P}_{2} \mathrm{O}_{5}, \mathrm{~T}-\mathrm{N}, \mathrm{CaO}$ 함량은 세스바니아가 다른 식물에 비하여 높았으며, $\mathrm{K}_{2} \mathrm{O}$ 은 수수 $\times$ 수단그라스가 $\mathrm{Na}_{2} \mathrm{O}$ 는 제주재래피가 약간씩 높게 나타났다. $\mathrm{T}-\mathrm{N}$ 의 함량 은 9월보다 8월에 높았으며 그 밖의 다른 원소들은 시기별 로 큰 차이를 보이지 않았다.

간척지구별 작물재배에 따른 토양 화학성 변화 내 염성 식물을 식재하는 것은 염생식물에서 비염생식물로의 변화를 가속시키며 제염을 촉진시킨다 (Lee et al., 2007). Ilyas et al. (1997)은 간척지 염류토양에 석고시용과 세스바 니아 등 내염성 식물재배에 의한 토양의 화학변화에 대한 연구를 수행한 결과 식물재배 후 $\mathrm{EC}$ 및 가용성 $\mathrm{Na}, \mathrm{SAR}$, $\mathrm{pH}$ 가 낮아지고 토양수분의 이동과 토양화학성이 좋아진다 고 보고하였다. 비교적 내염성이 강한 수수수단그라스, 세스바니아, 제주재래피 등을 재배한 후 간척지구별 토양의

Table 5. Chemical properties in response to green manure crop cultivation in the experimental sites.

\begin{tabular}{|c|c|c|c|c|c|c|c|c|c|c|c|c|}
\hline \multirow{2}{*}{ Area } & \multirow{2}{*}{ Crop } & \multirow{2}{*}{ Depth } & \multicolumn{2}{|c|}{$\mathrm{pH}$} & \multicolumn{2}{|c|}{$\mathrm{EC}$} & \multicolumn{2}{|c|}{$\mathrm{OM}$} & \multicolumn{2}{|c|}{$\mathrm{T}-\mathrm{N}$} & \multicolumn{2}{|c|}{$\mathrm{P}_{2} \mathrm{O}_{5}$} \\
\hline & & & Aug. & Sept. & Aug. & Sept. & Aug. & Sept. & Aug. & Sept. & Aug. & Sept. \\
\hline & & $\mathrm{cm}$ & \multicolumn{2}{|c|}{$1: 5$} & \multicolumn{2}{|c|}{$\mathrm{dS} \mathrm{m}^{-1}$} & \multicolumn{4}{|c|}{------- g kg $^{-1}$} & \multicolumn{2}{|c|}{$\mathrm{mg} \mathrm{kg}^{-1}$} \\
\hline \multirow{6}{*}{ Hwaong } & \multirow{2}{*}{ SS hybrid } & $0-15$ & 7.8 & 7.9 & 3.8 & 3.5 & 8.4 & 8.4 & 0.51 & 0.58 & 41 & 25 \\
\hline & & $15-30$ & 7.8 & 8.0 & 6.3 & 6.3 & 7.7 & 7.0 & 0.45 & 0.53 & 46 & 32 \\
\hline & \multirow{2}{*}{ Sesbania } & $0-15$ & 7.8 & 7.5 & 3.4 & 4.4 & 8.2 & 8.7 & 0.56 & 0.59 & 47 & 26 \\
\hline & & $15-30$ & 7.9 & 7.8 & 7.0 & 6.0 & 7.4 & 7.5 & 0.47 & 0.53 & 47 & 28 \\
\hline & \multirow{2}{*}{ Barnyard grass } & $0-15$ & 7.4 & 7.5 & 3.8 & 4.4 & 8.1 & 9.0 & 0.55 & 0.58 & 42 & 29 \\
\hline & & $15-30$ & 7.1 & 7.4 & 6.2 & 7.8 & 7.2 & 8.1 & 0.52 & 0.54 & 44 & 30 \\
\hline \multirow{6}{*}{ Ewon } & \multirow{2}{*}{ SS hybrid } & $0-15$ & 8.3 & 8.5 & 6.1 & 6.1 & 4.6 & 4.2 & 0.26 & 0.25 & 60 & 58 \\
\hline & & $15-30$ & 8.7 & 8.9 & 6.8 & 7.7 & 3.2 & 2.7 & 0.17 & 0.18 & 38 & 19 \\
\hline & \multirow{2}{*}{ Sesbania } & $0-15$ & 8.3 & 8.3 & 6.4 & 7.5 & 4.2 & 3.8 & 0.24 & 0.25 & 52 & 42 \\
\hline & & $15-30$ & 8.8 & 8.6 & 7.2 & 8.2 & 3.6 & 2.6 & 0.18 & 0.19 & 23 & 15 \\
\hline & \multirow{2}{*}{ Barnyard grass } & $0-15$ & 8.2 & 8.1 & 6.3 & 6.9 & 3.4 & 3.7 & 0.86 & 0.24 & 51 & 43 \\
\hline & & $15-30$ & 8.6 & 8.6 & 7.9 & 12.0 & 2.0 & 2.6 & 0.15 & 0.21 & 22 & 19 \\
\hline \multirow{6}{*}{ Saemangum } & \multirow{2}{*}{ SS hybrid } & $0-15$ & 6.5 & 7.9 & 0.9 & 0.5 & 2.4 & 3.0 & 0.17 & 0.18 & 43 & 27 \\
\hline & & $15-30$ & - & 8.8 & - & 1.9 & - & 2.6 & - & 0.17 & - & 21 \\
\hline & \multirow{2}{*}{ Sesbania } & $0-15$ & 7.1 & 8.0 & 0.7 & 0.2 & 2.5 & 2.6 & 0.16 & 0.17 & 35 & 26 \\
\hline & & $15-30$ & - & 9.3 & - & 0.7 & - & 2.5 & - & 0.18 & - & 22 \\
\hline & \multirow{2}{*}{ Barnyard grass } & $0-15$ & 7.4 & 8.1 & 0.4 & 0.1 & 2.6 & 3.2 & 0.16 & 0.13 & 41 & 20 \\
\hline & & $15-30$ & - & 9.4 & - & 0.7 & - & 3.2 & - & 0.15 & - & 22 \\
\hline \multirow{6}{*}{ Yongsangang } & \multirow{2}{*}{ SS hybrid } & $0-15$ & 8.6 & 8.5 & 2.7 & 1.3 & 8.1 & 11.8 & 0.45 & 0.48 & 33 & 56 \\
\hline & & $15-30$ & 8.8 & 8.9 & 2.9 & 1.8 & 5.9 & 9.0 & 0.32 & 0.36 & 22 & 25 \\
\hline & \multirow{2}{*}{ Sesbania } & $0-15$ & 8.5 & 8.3 & 3.2 & 1.6 & 7.5 & 8.7 & 0.44 & 0.51 & 36 & 32 \\
\hline & & $15-30$ & 8.8 & 8.6 & 3.0 & 2.7 & 5.7 & 6.8 & 0.34 & 0.34 & 27 & 21 \\
\hline & \multirow{2}{*}{ Barnyard grass } & $0-15$ & 8.3 & 8.6 & 2.9 & 1.1 & 7.0 & 11.1 & 0.45 & 0.48 & 37 & 29 \\
\hline & & $15-30$ & 8.5 & 8.7 & 3.0 & 2.4 & 4.8 & 8.2 & 0.30 & 0.33 & 30 & 17 \\
\hline
\end{tabular}


화학성을 조사한 결과를 Table 5 에 나타냈다. 화옹 지구의 경우 작물재배 전 표토의 $\mathrm{EC}$ 가 $4.3 \mathrm{dS} \mathrm{m}^{-1}$ 이었으나 재배 후 3.4-4.4 dS m m$^{-1}$ 로 토양 염농도가 약간 낮아지거나 비슷 한 수준이었다. 토양유기물의 경우 작물재배 전과 후의 변 화가 크지 않았다. 화옹 지구 표토 중 총질소의 함량은 작물 재배 전 함량은 $0.50 \mathrm{~g} \mathrm{~kg}^{-1}$ 이었는데 작물 수확기인 9 월에 는 수수수단그라스의 경우 $0.58 \mathrm{~g} \mathrm{~kg}^{-1}$, 세스바니아는 $0.59 \mathrm{~g} \mathrm{~kg}^{-1}$, 제주재래피는 $0.58 \mathrm{~g} \mathrm{~kg}^{-1}$ 로 나타났으며, 두과 식물인 세스바니아를 재배한 토양이 질소함량이 약간 높았 다. 유효인산의 함량은 8월보다 9월에 감소하였고, 경작전 보다는 경작후 감소하였다. 이원 지구에서 토양 화학성분의 변화를 살펴보면 토양유기물, 총질소, 유효인산의 함량 변 화는 특정한 경향이 없었다. 토양유기물과 총질소의 함량은 작물 재배 포장간 큰 차이를 보이지 않았다. 재배 전 토양과 비교했을 때 이원 지구 표토의 작물 재배 전 $\mathrm{EC}$ 는 $14.3 \mathrm{dS}$ $\mathrm{m}^{-1}$ 이었는데 재배 후에는 6.05-7.51 dS m${ }^{-1}$ 로 낮아졌으며, 토양유기물 함량은 재배 전, 후 특별한 경향이 없었다. 그러 나 유효인산의 경우 화옹 지구와 달리 작물재배 후 크게 증 가하였는데 작물재배 전 표토의 유효인산은 $14 \mathrm{mg} \mathrm{kg}^{-1}$ 에 서 작물재배 후 42-60 mg kg-1로 증가하였다.

내염성 식물을 재배하고 나면 식물잔재의 축적으로 토양 유기물이 점진적으로 증가하고 토양미생물 활동이 왕성해 져 토양 물리성과 화학성이 개선된다고 알려져 있다. 새만 금 지구의 경우 수수 $\times$ 수단그라스, 세스바니아, 제주재래피 를 재배한 후 토양화학성이 가장 크게 개선되는 효과가 있 었는데, 토양 $\mathrm{EC}$ 는 시험 전 $5.3 \mathrm{dS} \mathrm{m}^{-1}$ 이었던 것이 0.13-0.91 $\mathrm{dS} \mathrm{m}{ }^{-1}$ 로 $80 \%$ 이상 제염이 이루어졌는데 이는 작물재배의 효과도 있었지만 이 지역의 토성이 사양토로 강우 등 물에 의한 제염이 용이했기 때문으로 생각된다. 토양유기물 함량 은 시험 전 $0.8 \mathrm{~g} \mathrm{~kg}-1$ 이었는데 식물재배 후 $2.41-3.21 \mathrm{~g}$ $\mathrm{kg}^{-1}$ 으로 3-4배 증가하였고 총질소는 시험전 $0.16 \mathrm{~g} \mathrm{~kg}^{-1}$ 이 었던 것이 수수 $\times$ 수단그라스를 재배한 토양은 $0.17-0.18 \mathrm{~g}$ $\mathrm{kg}^{-1}$, 세스바니아를 재배한 토양은 $0.16-0.18 \mathrm{~g} \mathrm{~kg}^{-1}$ 로 $10 \%$ 정도 증가하였고 제주재래피를 재배한 토양은 $0.13-0.16 \mathrm{~g}$ $\mathrm{kg}^{-1}$ 로 토양 질소 함량이 약간 감소하였다. 유효인산은 식 물재배 후 증가하기도 하고 감소하기도 하여 일정한 경향을 알 수 없었으나 8월보다 9월에 감소하는 경향을 보였다.

영산강 지구의 경우 표토의 $\mathrm{EC}$ 값은 시험 전 $5.2 \mathrm{dS} \mathrm{m}^{-1}$

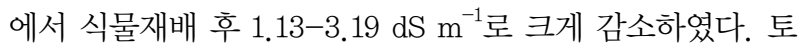
양유기물은 시험 전에 $10.0 \mathrm{~g} \mathrm{~kg}^{-1}$ 이었는데 수수×수단그라 스, 세스바니아, 제주재래피를 재배한 시험구에서 모두 감 소하였으며 8월보다는 9월에 증가하는 경향을 보였다. 토양 질소의 경우에는 모든 작물 재배구에서 증가하는 경향으로 나타났으며, 8월보다는 9월에 증가하는 경향을 보였다. 유 효인산의 경우 시험 전 $14 \mathrm{mg} \mathrm{kg}^{-1}$ 에서 작물재배 후 29-56 $\mathrm{mg} \mathrm{kg}{ }^{-1}$ 로 2-4배 증가하였다.

\section{간척지구별 녹비작물 토양환원시 양분공급량 산정} 간척지구별 수확기에 녹비작물을 전량 토양에 환원할 경우 토양에 투입되는 주요 양분의 공급 가능량은 Table 6 에 나 타냈다. 화옹 지구에서는 수수수단그라스가 37-28-94, 세스바니아가 137-33-113, 제주재래피가 56-36-103 kg $\mathrm{ha}^{-1}$ 이었으며, $\mathrm{T}-\mathrm{N}$ 과 $\mathrm{K}_{2} \mathrm{O}$ 는 세스바니아에서 가장 높았으 며, $\mathrm{P}_{2} \mathrm{O}_{5}$ 는 제주재래피에서 약간 높게 나타났다. 수수×수단 그라스는 모든 양분 공급량이 가장 낮게 나타났다. 이원 지 구에서는 수수×수단그라스가 91-33-159, 세스바니아가 138-29-114, 제주재래피가 74-23-75 kg ha ${ }^{-1}$ 이었으며, $\mathrm{P}_{2} \mathrm{O}_{5}$ 와 $\mathrm{K}_{2} \mathrm{O}$ 는 수수 $\times$ 수단그라스에서, $\mathrm{T}-\mathrm{N}$ 은 세스바니아에 서 가장 높게 나타났다. 제주재래피는 모든 양분 공급량이 가장 낮게 나타났다. 새만금 지구에서 수수×수단그라스가

Table 6. Nutrient contents of green manure corps at harvest time in the experimental sites.

\begin{tabular}{|c|c|c|c|c|c|c|c|c|}
\hline Area & Crop & Dry matter & $\mathrm{P}_{2} \mathrm{O}_{5}$ & $\mathrm{~T}-\mathrm{N}$ & $\mathrm{CaO}$ & $\mathrm{K}_{2} \mathrm{O}$ & $\mathrm{MgO}$ & $\mathrm{Na}_{2} \mathrm{O}$ \\
\hline & & $\mathrm{Mg} \mathrm{ha}^{-1}$ & \multicolumn{6}{|c|}{ 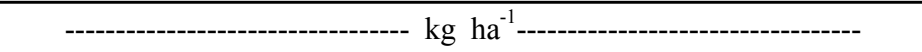 } \\
\hline & SS hybrid & 5.7 & 28.4 & 36.9 & 7.4 & 94.3 & 19.9 & 10.8 \\
\hline \multirow[t]{3}{*}{ Hwaong } & Sesbania & 8.1 & 32.5 & 137.2 & 32.5 & 112.9 & 14.6 & 34.1 \\
\hline & Barnyard grass & 7.3 & 35.6 & 56.0 & 9.5 & 102.6 & 25.5 & 57.5 \\
\hline & SS hybrid & 9.7 & 32.8 & 90.7 & 29.9 & 158.3 & 28.0 & 13.5 \\
\hline \multirow[t]{3}{*}{ Ewon } & Sesbania & 7.3 & 28.6 & 138.0 & 48.4 & 114.5 & 14.7 & 27.2 \\
\hline & Barnyard grass & 4.5 & 23.1 & 73.7 & 15.8 & 75.0 & 17.6 & 41.1 \\
\hline & SS hybrid & 20.3 & 42.7 & 146.2 & 18.3 & 367.6 & 50.8 & 8.1 \\
\hline \multirow[t]{3}{*}{ Saemangum } & Sesbania & 8.9 & 50.6 & 222.9 & 56.8 & 172.3 & 24.0 & 18.6 \\
\hline & Barnyard grass & 16.5 & 52.6 & 138.2 & 21.4 & 248.4 & 49.4 & 54.3 \\
\hline & SS hybrid & 10.7 & 50.4 & 79.3 & 32.2 & 323.7 & 36.4 & 7.5 \\
\hline \multirow[t]{2}{*}{ Yongsangang } & Sesbania & 4.3 & 27.3 & 97.4 & 41.1 & 76.6 & 9.1 & 8.2 \\
\hline & Barnyard grass & 5.1 & 24.6 & 35.9 & 11.8 & 70.3 & 15.4 & 22.6 \\
\hline
\end{tabular}


146-43-368, 세스바니아가 223-51-172, 제주재래피가 138-53-248 kg ha ${ }^{-1}$ 이었으며, T-N은 세스바니에서, $\mathrm{P}_{2} \mathrm{O}_{5}$ 는 제주재래피에서, $\mathrm{K}_{2} \mathrm{O}$ 는 수수×수단그라스에서 가장 높 게 나타났다. 영산강 지구에서 수수×수단그라스가 79-50-324, 세스바니아가 97-27-77, 제주재래피가 36-24-70 kg ha-1 이었으며, $\mathrm{T}-\mathrm{N}$ 은 세스바니아에서, $\mathrm{P}_{2} \mathrm{O}_{5}$ 와 $\mathrm{K}_{2} \mathrm{O}$ 는 수수 $\times$ 수 단그라스에서 가장 높게 나타났다. 제주재래피는 모든 양분 공급량이 가장 낮게 나타났다. $\mathrm{T}-\mathrm{N}$ 은 모든 간척지구에서 세스바니아 재배구가 가장 높았으며, $\mathrm{K} 2 \mathrm{O}$ 는 주로 수수 $\times$ 수 단그라스 재배구가 가장 높았다. $\mathrm{P}_{2} \mathrm{O}_{5}$ 는 모든 작물 재배구 가 거의 비슷하였다.

\section{Conclusions}

간척지 다각적 활용의 일환으로 밭작물을 도입하기 위하 여 화옹, 이원, 새만금, 영산강 등 4 개 신간척지의 토양환경 을 평가하고 녹비작물을 시험 재배하여 토양개량 효과와 작 물재배 가능성을 검토하였다. 대상 간척지 토양의 화학성을 조사한 결과 토양 $\mathrm{pH}$ 는 7.5-8.8 범위로 일반적인 밭토양의 적정범위보다 높았고, 유기물 함량은 $0.8-10.0 \mathrm{~g} \mathrm{~kg}^{-1}$, 유 효인산은 8-32 mg kg 으로 적정범위에 비해 매우 낮았다. 치환성 칼륨과 마그네슘은 적정범위보다 높았으나 칼슘은 적정범위보다 대체로 낮았다. 한편, 전 시험구에서 $\mathrm{Na}$ 함량 은 매우 높은 편이었다. 토양 물리성을 조사한 결과 입자분 포는 모래나 미사의 비율이 높은 반면 점토함량은 2.1-11.0\%로 매우 적었다. 용적밀도는 $1.35-1.60 \mathrm{Mg} \mathrm{m}$-3 범위로 일반적인 토양의 용적밀도보다 높은 값을 나타내고 있었다. 작물을 시험 재배한 결과 수량은 비교적 양호한 편 으로 간척지구에 따라 차이가 있었으며, 모든 작물이 새만 금 지구에서 가장 높은 수량을 나타냈다. 작물의 수확기 질 소 함량은 두과작물인 세스바니아에서 높았으며 새만금 지 구에서 수확기에 녹비작물을 전량 토양에 환원할 경우 토양 에 투입되는 주요 양분의 공급량은 수수 $\times$ 수단그라스가 150-40-370, 세스바니아가 220-50-170, 제주재래피가 140-50-250 kg ha ${ }^{-1}$ 로 질소와 칼리는 많고 인산은 적은 편 이었다. 이상과 같은 신간척지 4 개 지구의 토양 환경 조사 와 작물 시험재배의 결과로 미루어 볼 때 이들 간척지에 밭 작물을 도입하기 위해서는 첫째, 토양의 투수성 정도를 감 안하여 지하수위를 낮춘다든지 암거배수를 한다든지 등의 토양의 특성에 맞는 합리적인 제염방법 및 제염화 방지대책 을 모색하여 염농도를 작물이 원활히 생육할 수 있는 수준 으로 유지하고, 둘째, 작물의 뿌리 신장을 돕고 양분과 수분 의 보유력을 증가시킬 수 있도록 토양 물리성을 개선함과 아울러 작물의 생산성을 높일 수 있도록 토양 화학성을 적
정수준으로 끌어올리며, 셋째, 적절한 양분관리를 통하여 작물의 양분 이용률은 높이고 잉여 양분의 역외 유출은 억 제함으로써 친환경적 재배가 이루어지도록 하여야 할 것으 로 생각된다.

\section{References}

Ilyas, M., R.H. Qureshi, and M.A. Qadir. 1997. Chemical changes in a saline-sodic soil after gypsum application and cropping. Soil Technology. 10:247-260.

Kim, B.R., M.H. Kim, S.H. Han, J.S. Cho, and T.W. Kim. 2013. Agricultural trends and prospect. Agricultural prospect 2013. KREI. Seoul.

Koo, J.W., J.K. Choi, and J.G. Son. 1998. Soil properties of reclaimed tidel lands and tidelands of western sea coast in Korea. Korean J. Soil Sci. Fert. 31:120-127.

Lee, S.H., S.H. Yoo, S.I. Seol, Y. An, Y.S. Jung, and S.M. Lee. 2000. Assessment of salt damage for upland-crops in Dae-Ho reclaimed soil. Korea J. Environ. Agri. 19:358-363.

Lee, S.H., B.D. Hong, Y. An, and H.M. Ro. 2003. Relation between growth condition of six upland-crops and soil salinity in reclaimed land. Korean J. Soil Sci. Fert. 36:66-71.

Lee, K.B., M. Xu, J.D. Kim, and K.Y. Jung. 2006. Soil characteristics and utilization on reclaimed land in Jangsu province coastal region of China. Korean J. Intl. Agri. 18:245-252.

Lee, K.B., J.G. Kang, J. Li, D.B. Lee, C.W. Park, and J.D. Kim. 2007. Evaluation of salt-tolerance plant for improving saline soil of reclaimed land. Korean J. Soil Sci. Fert. 40:173-180.

NIAST. 2000. Methods of soil chemical analysis. National Institute of Agricultural Science and Technology, RDA, Suwon, Korea.

Park, J.H., J.K. Yeo, Y.B. Koo, W.W. Lee, H.C. Kim, and C.H. Park. 2008. Effects of slurry composting and biofiltration liquid fertilizer on growth characteristic of poplar clones in a reclaimed land mounding soil. Korean J. Soil Sci. Fert. 41:318-323.

Park, M.E., and S.H. Yoo. 1983. A comparison of soil hydraulic conductivities determined by three different methods in a sandy loam soil. Korean J. Soil Sci. Fert. 16:14-19.

Son, J.G., J.W. Koo, J.K. Choi, and J.D. Song. 2000. Determination of leaching requirements in the unripened tidal reclaimed paddy fields. Korean J. Soc. Agr. Eng. 42:55-62. 